a type of barley from its crude fibre content using a correction of I r K Kcal per supplementary point of crude fibre in the seed dry matter :

D.E. (Kcal $/ \mathrm{kg}$ D.M.) $=4.072$ - I I o crude fibre p. I00 D.M. $r=-0.96 \mathrm{I}^{* *}$

A prediction equation of the energy value of barley from their bulk weight is also suggested and discussed.

\title{
Influence of the type of barley (two-row; six row) on the performances of weaned piglets
}

\author{
J. B. BOUARD, J. FEKETL, M. LEUILLEF \\ Institut Technique des Céréales et des liourrages \\ 8, avenue du Président-Wilson, 75116 Paris
}

In a trial including 396 piglets weaned at 26 days large amounts of barley of two different types (SONJA: two-row winter barley, ASTRIX: six-row winter barley) and of different crude fibre contents ( 4.8 and 6.4 p. roo dry matter) were incorporated into the diets from 38 days of age and during 4 weeks. We applied to both types of barley the prediction equation of digestible energy established by PEREZ at al. (I980) in growing pigs. The difference in the energy value between both types was $5 \mathrm{p}$. I00; it was only $3.6 \mathrm{p}$. I 0 o between experimental diets rebalanced with protein.

'Two protein levels ( 18 and 22 p. IOo) were used for comparing the two types of barley. The response of the animals to the protein content was spectacular: for the same amount of feed ingested the growth and feed conversion ratio were improved by almost to p. Ioo. This suggests that in this protein range piglets react strongly and favourable provided that the herd management (breeding and health factors, environment) is satisfactory. Therefore, the comparison of different cereals for piglet diets requires use of the same protein level. This reduces the value of studies based on the quantitative substitution of cereals.

The same response was obtained in a previous study (BOUARD $e t$ al., 1979) where the compared protein levels were 18 and $20 \mathrm{p}$. I 00 . It seems to be a response to lysine rather than to the protein level, as confirmed by trials made in piglets with wheat or maize as only cereal. (BOUARD and IFKETK, I 978). The response of piglets to the decrease in the dietary energy level was an increase in the feed intake the relative value of which ( $3.9 \mathrm{p}$. I oo) was close to the theoretical energy difference ( 3.7 p.roo ). This kind of response well known in bacon pigs fed ad libitum was seldom noticed in piglets. However, it was demonstrated that when increasing the energy density of the diet by addition of fat the feed intake decreased in weaned piglets (O'GRADY and BOWI,AND, 1972; O'GRADY, 1978 ). The increased feed intake compensating for the lower energy value of six-row barley led to the same growth rate than two-row winter barley ( $54^{8} \mathrm{~g}$ a day).

These results suggest that as far as barley is concerned, feeding of weaned piglets may be similar to that of bacon pigs.

Hence, the prediction equations of the barley energy values established in growing pigs and based on Weende crude fibre content should be transposed to the younger animal from $8 / \mathrm{To} \mathrm{kg}$. 